\begin{tabular}{c}
\hline Review of \\
ECONOMICS \\
and \\
INSTITUTIONS
\end{tabular}

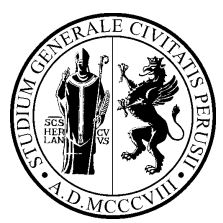

www.rei.unipg.it

\title{
Institutions and Financial Deepening
}

\author{
Kristine Farla ${ }^{\bowtie}$ \\ MGSoG/UNU-MERIT \\ Maastricht University
}

\begin{abstract}
This study investigates the extent to which institutional characteristics are related to countries' level of credit depth. The findings suggest that the development of formal property rights, contracting, and competition institutions is positively related to an increase in credit to the private sector as a ratio of GDP. This result remains robust when controlling for the effect of financial policy. The relation between institutional characteristics and banks' lending capacity and investment is mixed. However, overall, institutional development is positively related to credit deepening and investment.
\end{abstract}

JEL classification: G18; 011; 043;

Keywords: financial development, institutions

This study benefited from collaboration with the French Ministry for the Economy, Industry and Employment (MINEIE), the French Development Agency (AFD), from suggestions by Denis de Crombrugghe, Bart Verspagen, and two anonymous reviewers.

$\square$ Address: MGSoG/UNU-MERIT, Maastricht University, Keizer Karelplein 19, 6211 TC, Maastricht, the Netherlands (Phone: +31 4338844 00. Email: farla@merit.unu.edu)

\section{Recommended Citation}

Farla, K. (2014). Institutions and Financial Deepening. Review of Economics and Institutions, 5(2), Article 6. doi: 10.5202/rei.v5i2.98. Retrieved from http://www.rei.unipg.it/rei/article/view/98 


\section{Introduction}

Credit to the private sector in the Unites States, Japan, Canada, Germany, and China is higher than $100 \%$ of GDP. In countries in Sub-Saharan Africa credit to the private sector is, on average, lower than $20 \%$ of GDP. Why do these wide differences occur? And are they important? Credit deepening makes possible an increase in investment, an expansion of production, technological change, and economic growth, and attracts foreign direct investment. Levine (2005, p. 921) summarizes that "empirical analyses, including firm-level studies, industry-level studies, individual country-level studies, time-series studies, panel investigations, and broad cross-country comparisons, demonstrate a strong positive link between the functioning of the financial system and long-run economic growth". Similarly, the more recent study by Jeong and Townsend (2007) concludes that, in Thailand, financial deepening plays a substantial role in determining total factor productivity growth. Moreover, on the basis of a theoretical model, Greenwood et al. (2013, p. 211) predict that "world output could increase by 53 percent if all countries adopted the best financial practice in the world." 1 Closely related is the work of Greenwood et al. (2010) who establish a causal relation between the efficiency of financial intermediation, information frictions and economic development. On the basis of data on US firms, Gilchrist et al. (2013) specifically identify the degree of missallocation of resources that is attributable to financial market frictions. These authors use firms' borrowing costs as a proxy for financial market frictions and conclude that -in developed capital markets-financial market frictions only have a small effect on efficiency losses.

One possible effect of the development of stronger institutions is reducing financial market frictions which for example can lower the cost of lending, generate a higher lending base, and increase the financing of more longterm commitments. In this study we investigate what type of institutional characteristics enable firms' access to credit markets, and hence are related to financial deepening. Financial deepening is defined as an increase in the volume of credit as a proportion of GDP and the concept is measured using data on domestic credit to the private sector by financial intermediaries (the total value of loans, trade credits and non-equity securities), as a proportion of GDP.

The types of institutions that we are interested in are (1) property rights institutions, (2) contracting institutions and (3) competition institutions. There are several channels by which these types of institutions may influence financial deepening. First, we expect that strong property rights institutions secure property ownership over time. Weak security of property rights

1 When taking inefficiencies in the non-financial sector into account, this large potential impact of financial sector development on economic growth is substantially lower (Greenwood et al., 2013). 
can endanger investors' and borrowers' ability to retrieve future revenue from investment. This may have a negative impact on firms' ability to borrow and invest and may lower the size of loans. Moreover, Bae and Goyal (2009) find that banks issue higher loan amounts with longer loan maturities and request relatively lower loan spreads in countries with strong property rights protection than in countries with weak property rights protection. Second, we expect that strong contracting institutions reduce information asymmetry, the costs of contracting, the risk of contractual breach, and can enhance the credibility of contracting. Even though personalized contracting systems may be sufficient to protect 'small' loans and short-run lending arrangements, it is likely that substantial credit deepening requires strong contracting institutions. Third, the absence of competition institutions may create an environment that only supports the development of the existing industry. The monopolization of industry creates entry restrictions and can cause firms to under invest. A lack of competition is especially detrimental to small organizations, risky projects, and 'infant' firms' willingness to borrow. Moreover, a lack of competition could result in concentrated sectoral allocation of investment and general inefficient allocation of investment across sectors and project owners. Finally, monopolization of the banking industry can cause frequent breaching of contracts, lack of riskdiversification, and could undermine credibility in the financial system.

This study is closely related to the work of Acemoglu and Johnson (2005) who find that property rights protection has a positive influence on financial deepening (as well as on other indicators of economic performance). The authors find no effect on contracting institutions on financial deepening and hypothesize that contracting institutions are relatively unimportant because agents can change financial intermediation and terms of contracts. ${ }^{2}$ We revisit the relationship between institutions and financial deepening using alternative measurements of property rights protection and contracting institutions and additionally estimate the effect of competition institutions. Contrary to the methodological approach of Acemoglu and Johnson (2005), we construct indicators for property rights, contracting, and competition institutions using the same data source. To the best of our knowledge, the relevance of this combination of institutional characteristics has not been previously investigated in relation to financial development. The institutional indicators are transparent in their composition, comparable in scale and construction, and include both de-jure and de-facto perspectives on countries' institutional development. The institutional indicators describe institutional characteristics which are stable and inert in the medium/longterm. The Hausman-Taylor method with Amemiya-MaCurdy (1986) spec-

2 Similarly, Djankov et al. (2007) argue that private registries can stimulate the private sector by facilitating information exchange between firms. Djankov et al. also find evidence that in poorer countries the private credit to GDP ratio increases along with the introduction of credit registries. 
ification is used in order to retrieve the parameter estimates of these timeinvariant institutional indicators.

On the basis of panel data of 81 countries for the period 1994-2005, we conclude that there is a strong relationship between property rights, contracting and competition institutions and private sector credit deepening. Overall, the institutional indicators remain positive and significant when controlling for the effect of financial policy, and when using alternative measures of financial depth and investment.

\section{Empirical Approach}

\subsection{Institutional Indicators}

We construct institutional indicators using a relatively unexploited perception based survey, the Institutional Profiles Database (IPD, 2009). The variables selected describe institutional arrangements for property rights, contracting, and competition ${ }^{3}$ Some of the IPD variables (explicitly) comprise of both a de-jure and de-facto assessment of a countries' institutional rules. The IPD data describes 'stable' institutional arrangements and do not focus on describing current change in states' rule. Moreover, an advantage of using institutional data from the same source is that there is no difference in data collection and treatment. The data are fit for cross-country comparison and for comparison across indicators $4^{4}$

The IPD variables are listed below on the basis of a tentative categorization. Property rights institutions refer to regulations that protect current and future tangible and intangible property and revenues that originate from property, i.e., land and non-land assets and intellectual property. Contracting institutions consist of arrangements protecting the security of contracts, government respect for contracts, transparency in the banking system, enforcement of the justice system, creditor rights, the speed of rulings and effectiveness of commercial courts. Competition institutions refer to types of regulations that seek to "control or eliminate restrictive agreements or arrangements among enterprises, or mergers and acquisitions or abuse of dominant positions of market power, which limit access to markets or otherwise unduly restrain competition, adversely affecting domestic or inter-

3 This variable selection does not include variables that describe local and sub-national institutional arrangements, variables that describe costs for foreign actors, variables that describe change and reforms, survey questions that are not relevant for all countries, and survey questions that are unclear, ambiguous, or may be particularly difficult for country experts to answer.

4 Lack of cross-country and over time comparability is a weakness of data from the World Bank Worldwide Governance Indicators, the International Country Risk Rating (ICRG) / PRS Group, and the Fraser institute (De Crombrugghe, 2010). 
national trade or economic development" (UNCTAD, 2007, p. 3).5

Property rights institutions

- Effectiveness of legal measures to defend property rights between private agents (A6000)

- Degree of reasonable compensation in the event of de-jure or de-facto expropriation of land property (A6001)

- Degree of reasonable compensation in the event of de-jure or de-facto expropriation of property for production (A6002)

- Frequency of arbitrary government pressure on private property (e.g. using red tape) (A6003)

- Respect for intellectual property protection in terms of manufacturing secrets, patents (B6020)

- Respect for intellectual property protection in terms of counterfeiting (B6021)

Contract institutions

- Predictability of the results of public procurement contract bids (A3040)

- Independence of the commercial courts from the government in commercial disputes (A6020)

- Extent of enforcement and speed of commercial court rulings (A6023)

- Extent of enforcement of bankruptcy law (A6030)

Competition institutions

- Degree of administrative barriers (e.g. red tape) restricting firm entry (B7000)

- Effectiveness of competition regulation arrangements (non-banking) to combat restrictive collective agreements i.e. cartels (B7020)

- Effectiveness of competition regulation arrangements (non-banking) to combat abuses of dominant positions (B7021)

- Existence of competition arrangements in the banking system to combat restrictive collective agreements i.e. cartels (C7010)

- Existence of competition arrangements in the banking system to combat abuse of dominant position (C7011)

One observation is that, overall, higher scores on the variables are associated with formal institutional regulations. This observation is related to the work of Greif and Tabellini (2010) who argues that, in China, institutions rely more on an informal organization of enforcement and, in Europe, institutions rely more on a formal organization of enforcement. Hasan et al. (2009) note similar changes in institutions at the province level in China and argues that these changes have a positive effect on GDP growth. In this study we will explore whether formal institutional rules are associated with higher volumes of credit as a proportion of GDP.

${ }^{5}$ Competition policy generally comprises the following elements: antitrust and cartels, market liberalization, state aid control, and merger control. Because competition policy is formalized in countries' legal framework, in the context of this study we prefer the label 'competition institutions'. 
We consider the IPD data an interesting alternative to the data used, for example, by Acemoglu and Johnson (2005) to measure property rights and contracting institutions. Acemoglu and Johnson (as well as Tressel and Detragiache, 2008 and Quintyn and Verdier, 2010) measure property rights protection using data from Marshall and Jaggers (2009) as a proxy ${ }^{6}$ This data may be unfit to capture property rights institutions because, as described by Glaeser et al. (2004), 'constraint on the executive' is a volatile measurement which is more a reflection of the result of elections. 7 In order to measure the effect of contracting institutions on credit deepening, Acemoglu and Johnson (2005) use de-jure descriptions of legal arrangements intended to protect contracts. However, the existence of de-jure rules does not in itself guarantee that these rules are followed.

The core concern with estimating the relation between types of institutions and credit deepening when the using the IPD data is that the variables are empirically closely related: the correlation of the variables is around 0.6. We use principal component analysis (PCA) with varimax orthogonal rotation to create three institutional indicators. The varimax rotation method is chosen because it produces principal components (PCs) that contain high loadings for a few variables. ${ }^{8}$ Three PCs are retained because the variable selection is made with the objective to describe three institutional types (property rights, contracting and competition).

Figure 1 presents the results - the factor loadings-of the PCA. Principal component 1 (PC1) contains $32 \%$ of the total variation. This PC loads highly on the variables B7020, B7021, C7010, and C7011 which describe the degree of existence and effectiveness of competition regulations. PC1 is therefore interpreted as the component describing the degree of formalization of competition institutions. Countries that score highly on this PC are for example Ireland, Korea, and the Netherlands. Countries that score lowly on this PC are for example Kuwait, Qatar, and Mali. The lower bound of the PC captures countries that have little or no arrangements to stimulate competition.

Principal component 2 (PC2) contains 25\% of the total variation and loads highly on the variables A6001 and A6002. These variables describe the degree of reasonable compensation granted in the event of expropriation of property. PC2 is therefore identified as describing institutional rules

\footnotetext{
6 Tressel and Detragiache (2008, p. 16) argue that only countries with stronger constrains on executive experience sustainable financial acceleration after a financial reform, and that creditor rights, contract enforcement, and legal origins do not determine the success of sustainable financial accelerations. Similarly, Quintyn and Verdier (2010) find that countries' probability to achieve a period of sustained long-run financial development after a financial acceleration is positively influenced by 'constraint on executive' and the durability of democracy.

7 Following calculations on the basis of the sample of 88 countries used throughout this study, the indicator 'constraint on the executive' indeed has more variation over time than between countries.

8 The PCA is run using the 88 countries listed in Table 5 in the appendix. The PCA is run using the Stata command 'factor' with specification pcf.
} 
to secure property rights. The upper bound of PC2 describes countries that have secured property rights protection across sectors. Countries that score highly on this component are Slovenia, Czech Republic, and Kuwait. Countries that score lowly on component 2 are Pakistan, Cameroon, and Syria.

Principal component 3 (PC3) contains 21\% of the total variation and loads highly on variable A3040 which describes the predictability of the results of public procurement contract bids. This PC captures the de-facto role of the state in contracting. Countries that have transparent contracting regulations score on the upper bound of this component, for example Finland, Cyprus, and Philippines. Countries that score lowly on component 3 are Guatemala, Benin, and Chad. In the sequel, PC1 is referred to as Competition, PC2 as Property, and PC3 as Contract.

The results of the PCA do not fully confirm our tentative categorization of variables. In particular, we find that the variable B7000 which captures the degree of administrative barriers is relatively closer related to Contract. Also, variables B6021 and A6000 are relatively closer related to Contract than to Property. And, contrary to expectations, variables A6023 and A6030 load relatively higher on Competition. Excluding these variables from the PCA has no strong influence on the loadings of the other variables and therefore does not influence the interpretation of the PCs.

\section{Figure 1 - Construction of Orthogonal Institutional Measurements}

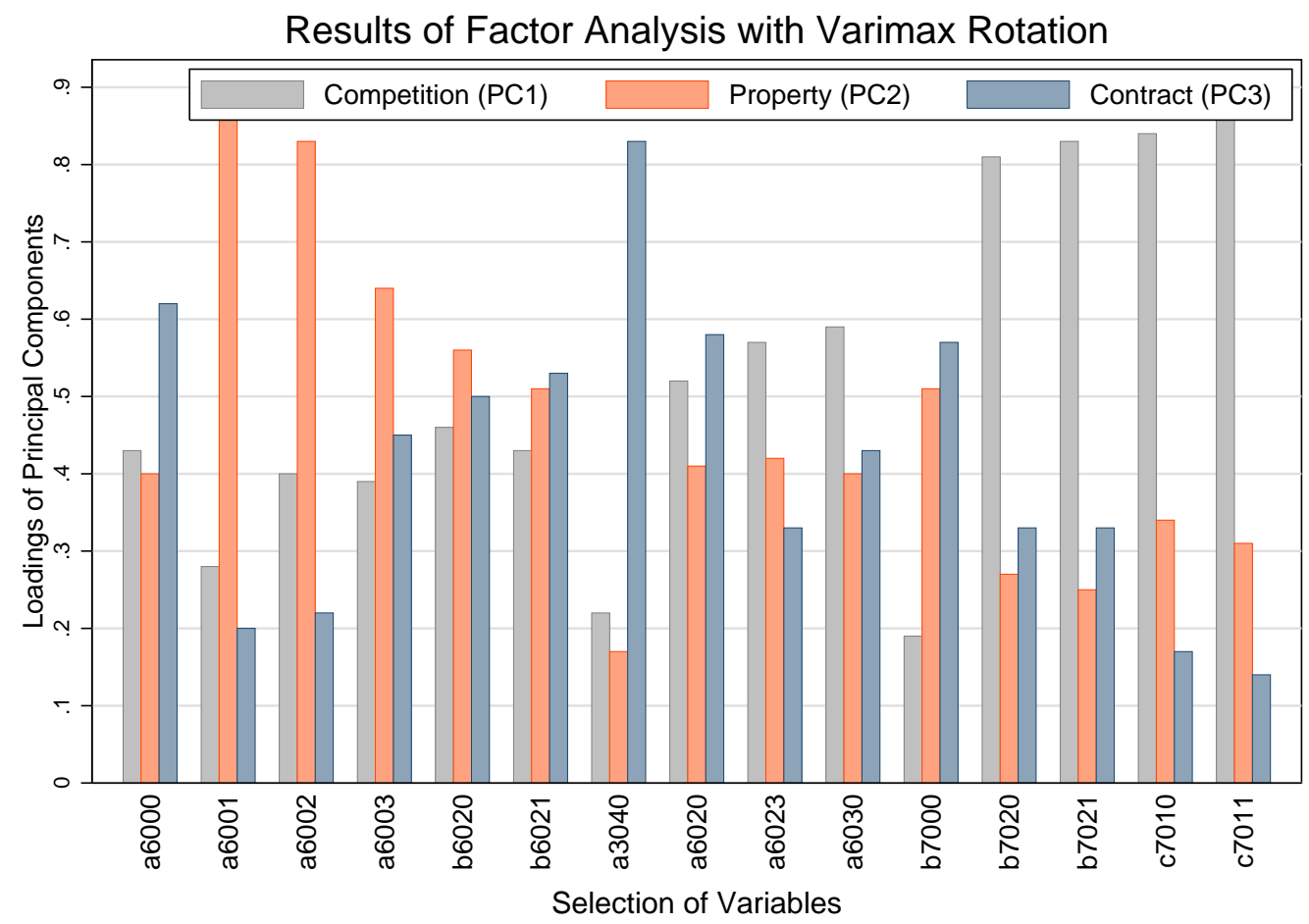


Figure 2 - Scatter Plots: Credit and Institutional indicators
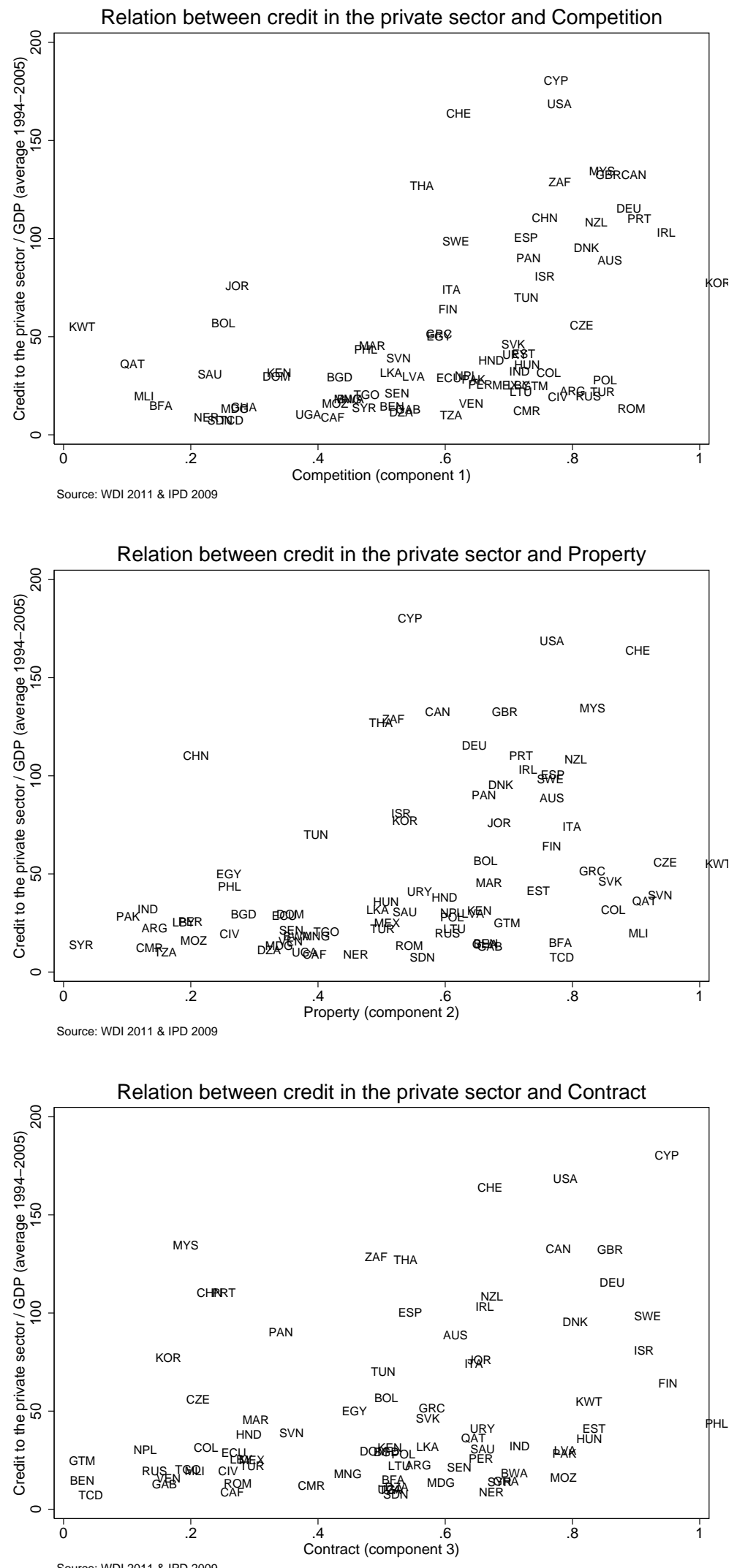
As illustrated in Figure 2, higher levels of credit in the private sector are associated with higher values of Competition, Property, and Contract. European countries score on the upper bound of the institutional indicators but differ substantially in the level of credit to the private sector. Some more pronounced differences between the institutional indicators include Qatar and Kuwait that score lowly on Competition but highly on Property. Syria, Philippines, and Pakistan score lowly on Property but highly on Contract. Chad, and the Czech Republic score lowly on Contract but highly on Property. Argentina, Cameroon, China, and India score lowly on Property but highly on Competition. Guatemala and Korea score lowly on Contract but highly on Competition.

\subsection{Model and Methodology}

The aim of this study is to estimate effects of the between-country difference of the institutional time-invariant (TI) indicators and both the betweencounty and over-time variation of the time-varying (TV) indicators. In this section, the basic model is introduced as well as some terminology that is used throughout the remainder of this study.

Our main methodological challenge is the estimation of the effect of TI institutional indicators without biases or inconsistencies. In an attempt to address such concerns, the model is estimated using a Hausman-Taylor estimator with Amemiya-MaCurdy (1986) specification, hereafter AM. The AM method builds on the instrumental variable method proposed by Hausman and Taylor (HT) (1981)..$^{9}$ The HT method estimates the parameters using the TV variables both to estimate their own coefficients and as instruments for the endogenous TI variables (Hausman and Taylor, 1981). The HT method uses the time-average of the TV exogenous variables as instruments. Amemiya and MaCurdy (1986) propose combining the betweencountry and over-time information of the TV exogenous variables as instruments. The model is mathematically represented by equation 1 below.

$$
Y_{i, t}=\beta X_{i, t}+\gamma Z_{i}+\alpha_{i}+\epsilon_{i, t}
$$

$Y_{i, t}$ is the dependent variable, the ratio of credit to the private sector to GDP in country $i$ in year $t . \alpha_{i}$ represents the unobservable country-specific effects. $\alpha_{i}$ is assumed a random variable that is distributed independently across our country sample with constant variance $\sigma_{\alpha}^{2} . \epsilon_{i, t}$ is the error term and is assumed to have a zero mean and constant variance $\sigma_{\epsilon}^{2}$, conditional on $X_{i, t}$ and $Z_{i}$. $X_{i, t}$ is a vector of TV indicators and is assumed to contain both exogenous and endogenous indicators. $Z_{i}$ is a vector of TI indicators

9 The Hausman-Taylor estimator with Amemiya-MaCurdy specification is typically used less frequently than the estimator of Hausman and Taylor (1981) because it requires balanced data. One alternative application of the model in the field of finance is that of Tchakoute-Tchuigoa(2012). 
and also is assumed to contain both exogenous and endogenous indicators. The endogenous part of $Z_{i}$ contains the institutional indicators. Only the between-country variation of the institutional characteristics is observed and the institutional characteristics are assumed inert in the medium-term.

The vector $X_{i, t}$ includes several macroeconomic indicators. Data sources are given in the appendix. We control for the effect of savings (Savings) on $Y_{i, t}$ because the availability of collateral is a major requirement for creditors. Countries' external debt (ExternalDebt) may be negatively related to financial development. Countries that have a large capital account surplus may rely on foreign funding for investment instead of stimulating saving and investment in the domestic economy. We control for the influence of exchange rates (ExchangeRate). Finally, we control for inflation (Inflation) measured as the rate of change in the consumer price index. High inflation discourages lending. All these variables are assumed to be exogenous, i.e., uncorrelated with $\alpha_{i}$ and $\epsilon_{i, t}$.

The following TI indicators are used: incidence of malaria (Malaria), temperate zones (Temperate), and ethnic (Ethnic), linguistic (Language), and religious fragmentation (Religion). ${ }^{10}$ These are all assumed to be exogenous.

On the one hand, several scholars argue that the development of institutions is related to deep historical roots; for instance see Spolaore and Wacziarg (2013) for a comprehensive overview of this literature. For example, Engerman and Sokoloff (1997) propose that countries' natural resources and climate influences institutional development. Acemoglu et al. (2001) argue that the incentives of establishing early settlements and developing formal property rights is related to malaria incidence and tropical climates. Similarly, tropical climates may be related to relative underdevelopment of contracting institutions. Also, it is more likely that industry developed in countries with temperate zones favorable to agricultural development. As a result, in such areas there may be a higher need for competition institutions. On the other hand, institutional formalization may be related to class fragmentation. The formalization of competition regulations may be influenced by ethnic fragmentation; high ethnic fragmentation may contribute to the economic/political dominance of a (small) ethnic majority. Countries with high linguistic fragmentation may have established more formal regulations to facilitate business. In countries with religious fragmentation, states may have had more incentive to separate the church from private sector regulations. Thereby, such countries may have early establishments of a

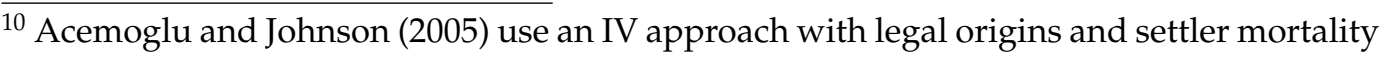
as instruments for property rights and contracting. These frequently used indicators are both based on the argument that the legal system and institutional heritage of countries influence today's institutions. Scholars have extensively argued that these indicators suffer from measurement bias, reverse-causality and/or estimations may suffer from omitted variable bias, in particular see Albouy. 2012 for a critique of Acemoglu et al. (2001) and the use of settler mortality data.
} 
more formal institutional setting.

In order to assess the sensitivity of the data to unobserved unit effects and reverse causality, the model is also tested using OLS with panel corrected standard errors (PCSE) ${ }^{11}$ and fixed effects vector decomposition, hereafter FEVD, 12

A Hausman specification test rejects a random effects model over a fixed effects model. A Hausman test of the difference between a FE model and Amemiya-MaCurdy (AM) yields a $\chi^{2}$ value of 0.37 , which is insignificant; this supports estimating using $\mathrm{AM} \cdot{ }^{13}$ The low $\chi^{2}$ statistic indicates that the coefficients of the FE estimation and the AM estimation are close. A Hausman test based on the difference between HT and AM yields a $\chi^{2}$ value of 3.47 which also is insignificant. Thereby, this Hausman test does not reject the additional exogeneity assumptions of AM.

\section{Results}

\subsection{Descriptive Statistics}

This study is based on a balanced panel dataset for the period 1994 to 2005. The sample of countries used throughout the analyses is listed in Table 5 in the appendix. ${ }^{14}$

There is substantial cross-country variation in credit to the private sector. The average of countries' ratio of credit to the private sector to GDP during 1994-2005 ranges from less than $10 \%$ to more than $150 \% \cdot 15$ Based on our

${ }^{11}$ PCSEs, as proposed by Beck and Katz (1995), correct for 'extreme overconfidence' and yield standard errors that are within $10 \%$ of the true variability, also for data containing heteroskedasticity and contemporaneously correlated errors. PCSE does not address unit effects.

12 The FEVD estimates for TV variables are the same as Fixed Effect (FE) estimates and are assumed endogenous. Unlike FE estimations, FEVD estimates TI variables in panel data models with unit effects. TI variables are assumed exogenous and the method does not control for causality. FEVD and HT estimators provide equal results when all TV variables are treated as endogenous and the TI variables are treated as exogenous (Breusch et al. 2011). FEVD has received several critiques, e.g. see Greene (2011), Chatelain and Ralf (2010) and Breusch et al. (2011). The FEVD estimations here are based on an updated 2009 version (xtfevd4.0beta.ado) with revised standard errors (Plumper and Troeger, 2011).

13 The Hausman tests are based on the estimations presented in Table 1 where Competition, Property, and Contract are endogenous.

14 The countries Azerbaijan, Brazil, Bulgaria, Democratic Republic of Congo, Iran, India, Kazakhstan, Paraguay, Ukraine, Zimbabwe, and Zambia are not included in the sample because of hyperinflation rates and/or high levels of exchange rate over-valuation.

15 The dependent variable Credit has missing data for the following countries: Austria, Belgium, France, Mauritania, Netherlands, and Norway. These countries are excluded when using the variable Credit. In addition, Japan is excluded because of the country's high level of Credit. For some countries, data on the credit claims includes credit to 
sample, the average ratio of credit to GDP is $47.35 \%$.

\subsection{Main Results}

Table 1 reports the relation between credit to the private sector and institutional characteristics whilst controlling for macroeconomic influences. Column 1 to 3 report the estimation results using the different regression methods. There is a strong and significant relationship between credit and the formalization of institutional characteristics. Unlike the OLS with PCSE and FEVD methods, the AM method seeks to control for endogeneity of the institutional indicators. The magnitude of the institutional coefficients is relatively similar which may indicate that there is limited reverse causality between credit deepening and the development of formal institutional rules. Alternatively, one possibility is that the AM method is not sufficient to address endogeneity and therefore, we cannot exclude the possibility of reverse causality: i.e. that credit deepening triggers the establishment of more formal institutional rules.

The AM estimations in column 3 report that the formalization of competition, property and contract institutions is significantly and positively related to credit deepening ${ }^{16}$ The coefficients of Temperate and Malaria are significant at a $10 \%$ level and have a direct relation with credit deepening. Following the results of the OLS estimation, Religion and Language are also related to credit deepening. The coefficients of ExternalDebt and Savings have the expected sign, are significant, and the estimations are relatively constant across regressions. The coefficients of Inflation and ExchangeRate are close to zero. We also experimented using institutional proxies that exclude some IPD variables (i.e. B7000, B6021, A6000, A6023, and A6030) which can be considered 'misclassified' in the construction of Competition, Property, and Contract. These results likewise suggest a significant and positive relation between the institutional variables and credit as a proportion of GDP.

Column 4 in Table 1 reports the aggregate / combined magnitude of the formalization of institutional characteristics on the private sector, measured by Composite. Composite is measured by the first retained PC from an unrotated PCA on the total selection of IPD variables. Unrotated PCA yields only one strong institutional dimension. Composite contains $66 \%$ of the total variation and loads on all underlying variables. ${ }^{17}$ The coefficient of Composite indicates the overall degree to which the institutional character-

public enterprises.

${ }^{16}$ The first PC (Competition) contains the highest of the total variation and therefore we expect that this PC is more closely related to the overall dimension of institutional formalization than Property and Contract. For this reason, the relative contribution of each institutional characteristics is not emphasized.

${ }^{17}$ The second PC contains $7 \%$ of the variation and the third PC contains $5 \%$ of the variation. 
istics are related to financial depth ${ }^{18}$ The coefficient of Composite is higher than the coefficient of Competition, Property and Contract. The effect of overall institutional quality on financial deepening appears to be substantial. The coefficient of Composite in the AM model, column 4, suggests that, on average, a one standard deviation increase in this variable is associated with a 0.71 standard deviation increase in credit to the private sector as a percentage of GDP ${ }^{19}$

One concern with data on credit to the private sector is that high levels of credit may be an indication of excess borrowing and of suboptimal allocation of credit. Especially since 2008, it is undeniable that rapid private credit build-up, caused by financial system deregulation and privatization, can have a negative impact on economic growth. Additionally, Arcand et al. (2013) shows that bailouts can cause the financial sector to increase beyond the socially optimum level. As such, there are limitations to the extent to which financial deepening is beneficial to growth. This has also been recognized by previous literature, such as Reinhart and Rogoff (2009) Kindleberger and Aliber (2005), and Minsky (1986). Arcand et al. (2012) find that financial deepening is negatively related to economic growth when the ratio of credit to GDP reaches (roughly) 100\%.

For the years 1994-2005, the average ratio of credit to GDP exceeds $100 \%$ for the following countries: New Zealand, Portugal, China, Germany, Thailand, South Africa, United Kingdom, Canada, Malaysia, Switzerland, United States, and Cyprus. The above mentioned countries are excluded in the analysis presented in column 5 and 6 of Table 1. By comparing the results in column $3,4,5$, and 6 , we can identify the extent to which the estimations are influenced by countries with high levels of credit to the private sector.

Specifically, the coefficient of Competition is lower in column 5 compared to column 3 suggesting that competition institutions is more important for countries with high levels of credit. One possible explanation is that countries that have a relatively small private sector are typically countries that have lower credit as a ratio of GDP. And, because in such countries there is a basic absence of competition there are less incentives to develop rules to stimulate competition. The coefficient for Property is higher in column 5 compared to column 3 suggesting that property rights protection is more important for countries with low or moderate levels of credit. Although this finding is somewhat surprising one explanation is that countries with a relatively high ratio of credit to GDP invest more in tertiary sectors which are less dependent on property rights protection. The magnitude of the coefficient of Composite is higher in column 3 than in column 5. This suggests that, overall, the private sector is less influenced by the formalization of in-

\footnotetext{
18 The results of the Hausman tests in section 2.2 are confirmed when Competition, Property, and Contract are replaced by Composite.

${ }^{19}$ Analysis using FEVD and OLS with PCSE and the composite indicator likewise suggests a significant and positive relation between institutions and credit deepening.
} 
stitutional rules in countries with lower levels of credit.

Table 1 - Regression Results: Dependent Variable Credit

\begin{tabular}{|c|c|c|c|c|c|c|}
\hline & $\begin{array}{c}(1) \\
\text { FEVD }\end{array}$ & $\begin{array}{c}(2) \\
\text { OLS with PCSE }\end{array}$ & $\begin{array}{c}(3) \\
\mathrm{AM} \diamond\end{array}$ & $\begin{array}{c}(4) \\
\mathrm{AM} \diamond\end{array}$ & $\begin{array}{c}(5) \\
\mathrm{AM} \diamond\end{array}$ & $\begin{array}{c}(6) \\
\mathrm{AM} \diamond\end{array}$ \\
\hline Competition & $\begin{array}{l}0.52^{* * *} \\
(0.00)\end{array}$ & $\begin{array}{l}0.52^{* * *} \\
(0.00)\end{array}$ & $\begin{array}{l}0.51^{* *} \\
(0.01)\end{array}$ & & $\begin{array}{l}0.39^{* *} \\
(0.01)\end{array}$ & \\
\hline Property & $\begin{array}{c}0.38^{* * *} \\
(0.00)\end{array}$ & $\begin{array}{l}0.36^{* * *} \\
(0.00)\end{array}$ & $\begin{array}{l}0.40^{*} \\
(0.01)\end{array}$ & & $\begin{array}{c}0.44^{* * *} \\
(0.00)\end{array}$ & \\
\hline Contract & $\begin{array}{l}0.39^{* * *} \\
(0.00)\end{array}$ & $\begin{array}{c}0.35^{* * *} \\
(0.00)\end{array}$ & $\begin{array}{l}0.39 * * \\
(0.01)\end{array}$ & & $\begin{array}{l}0.37^{* *} \\
(0.00)\end{array}$ & \\
\hline Composite & & & & $\begin{array}{l}0.71^{* * *} \\
(0.00)\end{array}$ & & $\begin{array}{c}0.63^{* * *} \\
(0.00)\end{array}$ \\
\hline Language & $\begin{array}{c}0.06 \\
(0.60)\end{array}$ & $\begin{array}{l}0.03^{* *} \\
(0.00)\end{array}$ & $\begin{array}{c}0.06 \\
(0.75)\end{array}$ & $\begin{array}{c}0.06 \\
(0.67)\end{array}$ & $\begin{array}{l}-0.07 \\
(0.66)\end{array}$ & $\begin{array}{l}-0.05 \\
(0.68)\end{array}$ \\
\hline Ethnic & $\begin{array}{l}-0.03 \\
(0.81)\end{array}$ & $\begin{array}{l}-0.00 \\
(0.78)\end{array}$ & $\begin{array}{l}-0.04 \\
(0.85)\end{array}$ & $\begin{array}{l}-0.05 \\
(0.74)\end{array}$ & $\begin{array}{l}-0.11 \\
(0.45)\end{array}$ & $\begin{array}{l}-0.10 \\
(0.45)\end{array}$ \\
\hline Malaria & $\begin{array}{l}-0.34^{* *} \\
(0.01)\end{array}$ & $\begin{array}{l}-0.31^{* * *} \\
(0.00)\end{array}$ & $\begin{array}{r}-0.33+ \\
(0.09)\end{array}$ & $\begin{array}{l}-0.33^{*} \\
(0.03)\end{array}$ & $\begin{array}{l}-0.17 \\
(0.30)\end{array}$ & $\begin{array}{l}-0.19 \\
(0.20)\end{array}$ \\
\hline Temperate & $\begin{array}{l}-0.37^{* *} \\
(0.00)\end{array}$ & $\begin{array}{l}-0.35^{* * *} \\
(0.00)\end{array}$ & $\begin{array}{r}-0.37+ \\
(0.08)\end{array}$ & $\begin{array}{l}-0.37^{*} \\
(0.03)\end{array}$ & $\begin{array}{l}-0.25 \\
(0.13)\end{array}$ & $\begin{array}{r}-0.27+ \\
(0.06)\end{array}$ \\
\hline Religion & $\begin{array}{l}0.15+ \\
(0.07)\end{array}$ & $\begin{array}{l}0.15^{* * *} \\
(0.00)\end{array}$ & $\begin{array}{c}0.15 \\
(0.26)\end{array}$ & $\begin{array}{c}0.16 \\
(0.14)\end{array}$ & $\begin{array}{c}0.00 \\
(0.97)\end{array}$ & $\begin{array}{c}0.00 \\
(0.98)\end{array}$ \\
\hline ExternalDebt & $\begin{array}{l}-0.11^{* * *} \\
(0.00)\end{array}$ & $\begin{array}{l}-0.12^{* *} \\
(0.00)\end{array}$ & $\begin{array}{l}-0.11^{* * *} \\
(0.00)\end{array}$ & $\begin{array}{l}-0.11^{* * *} \\
(0.00)\end{array}$ & $\begin{array}{l}-0.18^{* * *} \\
(0.00)\end{array}$ & $\begin{array}{c}-0.18^{* * *} \\
(0.00)\end{array}$ \\
\hline Savings & $\begin{array}{l}0.13^{* * *} \\
(0.00)\end{array}$ & $\begin{array}{l}0.12^{* *} \\
(0.00)\end{array}$ & $\begin{array}{l}0.13^{* * *} \\
(0.00)\end{array}$ & $\begin{array}{l}0.13^{* * *} \\
(0.00)\end{array}$ & $\begin{array}{l}0.21^{* * *} \\
(0.00)\end{array}$ & $\begin{array}{l}0.20^{* * * *} \\
(0.00)\end{array}$ \\
\hline Inflation & $\begin{array}{r}-0.02+ \\
(0.08)\end{array}$ & $\begin{array}{l}-0.16^{* * *} \\
(0.00)\end{array}$ & $\begin{array}{r}-0.02+ \\
(0.05)\end{array}$ & $\begin{array}{l}-0.03^{*} \\
(0.04)\end{array}$ & $\begin{array}{l}-0.04^{*} \\
(0.02)\end{array}$ & $\begin{array}{l}-0.05^{*} \\
(0.01)\end{array}$ \\
\hline ExRate & $\begin{array}{l}-0.01 \\
(0.62)\end{array}$ & $\begin{array}{c}-0.08^{* * *} \\
(0.00)\end{array}$ & $\begin{array}{l}-0.02 \\
(0.54)\end{array}$ & $\begin{array}{l}-0.02 \\
(0.49)\end{array}$ & $\begin{array}{l}-0.03 \\
(0.49)\end{array}$ & $\begin{array}{l}-0.03 \\
(0.43)\end{array}$ \\
\hline $\begin{array}{l}N \\
R^{2}\end{array}$ & $\begin{array}{l}972 \\
0.91\end{array}$ & $\begin{array}{l}972 \\
0.55\end{array}$ & 972 & 972 & 828 & 828 \\
\hline
\end{tabular}

Standardized beta coefficients; $p$-values in parentheses

$+p<0.10,{ }^{*} p<0.05,{ }^{* *} p<0.01,{ }^{* * *} p<0.001$

$\diamond$ exogenous $=$ ExternalDebt, Savings, Inflation, ExchangeRate, Language, Malaria, Ethnic,

Temperate, Religion. $\diamond$ endogenous $=$ Competition, Property, Contract, Composite .

\subsection{Institutions - Policy Mix}

Financial policy is an important tool for states by which they can influence the allocation of credit. Financial policy may have a positive or a negative impact on credit deepening. We control for the effect of financial policy on credit to the private sector using three indicators from Abiad et al. (2010). We use a smaller sample of 61 countries $\sqrt{20}$ We control for the influence of

20 The following countries are excluded because of missing policy data: Benin, Botswana, Central African Republic, Cyprus, Gabon, Honduras, Kuwait, Libya, Mali, Mongolia, 
the degree of privatization of banks (Privatization, decrease in State ownership), for the effect of the degree of bank supervision (Supervision, decrease in independence from executive influence), and for the effect of entry barriers in the banking sector (Barriers, decrease in state control over credit allocation). These TV policy indicators are assumed to be endogenous.

High scores on the indicator Privatization indicate relatively more privatized banks. One possibility is that the privatization of banks results in more lending to the private sector. La Porta et al. (2002) find that countries with high government ownership of banks have lower financial development, productivity and growth. ${ }^{21}$ Privatization could result in more efficient and effective allocation of credit and privatization could result in higher competition, increasing borrowing opportunities for organizations. However, Yeyati et al. (2007), using more recent data than that used in the work of La Porta et al. (2002), find some evidence which indicates that there is no significant relation between state ownership of banks and credit to the private sector. Overall, these authors argue that the relationship between state ownership of banks and financial deepening is more complex than was previously outlined by La Porta et al. (2002). Related research by Andrianova et al. (2008) suggests that, in comparison to government-owned banks, the cost of borrowing is generally higher in privatized banks. ${ }^{22}$ Also in contrast to the evidence of La Porta et al. Detragiache et al. (2008) find a negative relation between state-owned banks and the volume of credit as a proportion of GDP.

High scores on the indicator Supervision represent relatively more government intervention of the banking sector. Banking supervision may increase transparency. The implementation of prudential regulations can restrain the allocation of credit into unproductive, high risk projects. In the 1980 's, the objective of most high-income countries was financial market deregulation. Since 2008, deregulation is heavily debated by stakeholders with the aim to re-gain control over financial safety.

\footnotetext{
Mauritania, Niger, Panama, Qatar, Saudi Arabia, Sudan, Slovak Republic, Slovenia, Syrian Arab Republic, Chad, and Togo. In addition, the following countries are excluded: Austria, Belgium, France, Netherlands, Norway, and Japan. See also footnote 15

${ }^{21}$ Following the political view, La Porta et al. (2002) explain that "government ownership leads to missallocation of resources" and that "governments are less able to use banks they own to redistribute wealth to political supporters when they are subject to greater oversight by the electorate. As a consequence they have less interest in owning such banks" (La Porta et al. 2002, p. 188,179). As explained by Yeyati et al. (2007, pp. 2010), the political view is contrasted with a development view "which stresses the need for public intervention in economies where the scarcity of capital, the general distrust of the public, and endemic fraudulent practices amongst debtors may fail to generate the sizable financial sector required to facilitate economic development."

${ }^{22}$ Government-owned banks may select less risky projects to finance. On the basis of a model of banking Andrianova et al. (2008, p. 230) find that "where private and government-owned banks co-exist, the former will offer a higher interest rate to depositors reflecting the higher risk".
} 
The indicator Barriers captures the degree of entry restrictions of banks' activities including restrictions on foreign banks and geographic restrictions on operations. High scores on this indicator represent a more liberal banking sector. The relationship between a more liberal banking sector and financial deepening is ambiguous. One the one hand, it is possible that entry barriers restrict the lending capacity of the financial sector and drive up the cost of borrowing which in return can cause a lower demand for credit. Therefore, the liberalization of the banking sector may increase financial sectors' aggregate lending capacity. On the other hand, as described in the work of Detragiache et al. (2008), foreign banks' presence may crowd out domestic banks resulting in a decrease in aggregate credit. And, on the basis of a theoretical model and empirical evidence, Detragiache et al. find that the presence of foreign banks is associated with relatively lower levels of credit.

Table 2 reports the regression results that include the policy indicators. Column 1 and 2 report that there is a relation between banking supervision and entry barriers and the ratio of credit to GDP. The coefficients of Supervision and Barriers are positive, albeit low. The positive coefficient Barriers may suggest that the overall level of credit to the private sector is higher in countries with fewer restrictions in the banking sector (thereby this interpretation does not support the theory of Detragiache et al. (2008) on the role of foreign banks). Alternatively, one possibility is that fewer restrictions in the banking sector is associated with small economies (low GDP). The coefficient for banking privatization is not significant which supports the empirical findings of Yeyati et al. (2007) rather than that of La Porta et al. (2002).

The coefficient of Temperate is significant at a $1 \%$ level, and that of Malaria is significant at a 5\% level. The coefficients for Temperate and Malaria are substantially higher in Table 2 than in Table 1 . The coefficient of Religion is significant at a $10 \%$ level. On the one hand, when controlling for policy, the coefficients of Contract, Property and Composite are higher. On the other hand, the coefficient for Competition is lower. The change in the coefficient of Competition is not surprising because market competition regulations and the types of financial policy discussed above are closely related aspects in terms of public sector governance.

\subsection{Alternative Dependent Variables}

In this section, we present the estimation results using alternative dependent variables. ${ }^{23}$ First, we examine the relation between the institutional

${ }^{23}$ As in section 3.3. countries with missing policy data are excluded. See also footnote 20. Data sources are given in the appendix. 
Table 2 - AM Regression Results: Dependent variable Credit

\section{(1)}

$(2)$

\begin{tabular}{|c|c|c|}
\hline Competition & $0.39^{*}$ & \\
\hline & $(0.02)$ & \\
\hline Property & $0.44^{* *}$ & \\
\hline & $(0.00)$ & \\
\hline Contract & $\begin{array}{l}0.40^{* *} \\
(0.00)\end{array}$ & \\
\hline Composite & & $\begin{array}{c}0.73^{* * *} \\
(0.00)\end{array}$ \\
\hline Privatization & $\begin{array}{c}-0.02 \\
(0.50)\end{array}$ & $\begin{array}{l}-0.02 \\
(0.49)\end{array}$ \\
\hline Supervision & $\begin{array}{l}0.07^{* *} \\
(0.00)\end{array}$ & $\begin{array}{l}0.07^{* *} \\
(0.00)\end{array}$ \\
\hline Barriers & $\begin{array}{l}0.09^{* * *} \\
(0.00)\end{array}$ & $\begin{array}{l}0.09^{* *} \\
(0.00)\end{array}$ \\
\hline Language & $\begin{array}{c}0.02 \\
(0.91)\end{array}$ & $\begin{array}{c}0.01 \\
(0.93)\end{array}$ \\
\hline Ethnic & $\begin{array}{c}-0.03 \\
(0.89)\end{array}$ & $\begin{array}{l}-0.01 \\
(0.96)\end{array}$ \\
\hline Malaria & $\begin{array}{l}-0.42^{*} \\
(0.03)\end{array}$ & $\begin{array}{l}-0.40^{*} \\
(0.02)\end{array}$ \\
\hline Temperate & $\begin{array}{c}-0.62^{* *} \\
(0.01)\end{array}$ & $\begin{array}{c}-0.61^{* *} \\
(0.00)\end{array}$ \\
\hline Religion & $\begin{array}{l}0.22+ \\
(0.09)\end{array}$ & $\begin{array}{l}0.21+ \\
(0.06)\end{array}$ \\
\hline ExternalDebt & $\begin{array}{c}-0.15^{* * *} \\
(0.00)\end{array}$ & $\begin{array}{c}-0.15^{* * * *} \\
(0.00)\end{array}$ \\
\hline Savings & $\begin{array}{c}0.24^{* * *} \\
(0.00)\end{array}$ & $\begin{array}{c}0.24^{* * *} \\
(0.00)\end{array}$ \\
\hline Inflation & $\begin{array}{l}-0.02 \\
(0.34)\end{array}$ & $\begin{array}{l}-0.02 \\
(0.31)\end{array}$ \\
\hline ExchangeRate & -0.04 & -0.05 \\
\hline & $(0.21)$ & $(0.18)$ \\
\hline$N$ & 732 & 732 \\
\hline
\end{tabular}

Standardized beta coefficients; $p$-values in parentheses $+p<0.10,{ }^{*} p<0.05,{ }^{* *} p<0.01,{ }^{* * *} p<0.001$

Exogenous = ExternalDebt, Savings, Inflation, ExchangeRate,

Language, Malaria, Ethnic, Temperate, Religion. Endogenous = Competition, Property, Contract, Composite, Privatization, Supervision, Barriers. 
characteristics and the level of domestic bank credit to the private sector (BankCredit) ${ }^{24}$ Unlike the dependent variable Credit, this indicator does not include the volume of credit issued by development banks. The correlation between these indicators is 0.97 . Second, we test our model using the ratio of bank deposits to GDP ${ }^{25}$ The correlation between Credit and BankDeposit is 0.85. Third, the model is also estimated using investment as a share of GDP as the dependent variable (Investment). The correlation between Credit and Investment is 0.49 .

The estimations results are reported in Table 3. When using BankCredit as the dependent variable the AM method yields coefficients for the institutional indicators that are relatively similar to those presented in Table 2. In column 3 and 4, Property, Contract, and Composite are significantly related to the ratio of bank deposits to GDP, although the magnitude of the estimated effects is lower. The coefficient for Competition is not significant. This suggests that banks' lending capacity is dependent on the formalization of property rights and contracting but is unrelated to competition institutions.

The regression results in column 5, with Investment as the dependent variable, indicate that formal competition institutions has a positive and significant relation with the ratio of investment to GDP. Composite is likewise related to Investment, presumably because of the underlying competition indicator. The coefficients for Property and Contract are not significant. Countries that have substantially higher levels of investment have implemented formal competition institutions. Some oil rich countries have strong property rights protection but have relatively low competition and relatively lower levels of investment as a percentage of GDP. This could imply that the translation of credit deepening into higher levels of investment requires the implementation of competition regulations. When using investment as the dependent variable, the coefficients of Temperate are close to zero whilst the coefficients for ExternalDebt and Savings are high.

\footnotetext{
${ }^{24}$ This regression analysis does not include data for Austria, Belgium, Botswana, France, Japan, Netherlands, and Norway.

${ }^{25}$ The countries Austria, Belgium, Bangladesh, China, France, Japan, Libya, Netherlands, and Qatar are excluded from this regression analysis.
} 
Table 3 - AM Regression Results: Alternative Dependent Variables

\begin{tabular}{|c|c|c|c|c|c|c|}
\hline & $\begin{array}{c}(1) \\
\text { BankCredit }\end{array}$ & $\begin{array}{c}(2) \\
\text { BankCredit }\end{array}$ & $\begin{array}{c}\text { (3) } \\
\text { BankDeposit }\end{array}$ & $\begin{array}{c}(4) \\
\text { BankDeposit }\end{array}$ & $\begin{array}{c}\text { (5) } \\
\text { Investment }\end{array}$ & $\begin{array}{c}\text { (6) } \\
\text { Investment }\end{array}$ \\
\hline Competition & $\begin{array}{l}0.36^{*} \\
(0.03)\end{array}$ & & $\begin{array}{c}0.35 \\
(0.11)\end{array}$ & & $\begin{array}{c}0.34^{*} \\
(0.04)\end{array}$ & \\
\hline Property & $\begin{array}{l}0.43^{* *} \\
(0.00)\end{array}$ & & $\begin{array}{l}0.53^{* *} \\
(0.01)\end{array}$ & & $\begin{array}{c}0.19 \\
(0.21)\end{array}$ & \\
\hline Contract & $\begin{array}{l}0.40^{* * *} \\
(0.01)\end{array}$ & & $\begin{array}{l}0.39^{*} \\
(0.04)\end{array}$ & & $\begin{array}{c}0.04 \\
(0.75)\end{array}$ & \\
\hline Composite & & $\begin{array}{l}0.70^{* * *} \\
(0.00)\end{array}$ & & $\begin{array}{l}0.76^{* * *} \\
(0.00)\end{array}$ & & $\begin{array}{l}0.32^{*} \\
(0.02)\end{array}$ \\
\hline Privatization & $\begin{array}{c}-0.09^{* *} \\
(0.00)\end{array}$ & $\begin{array}{l}-0.09^{* *} \\
(0.00)\end{array}$ & $\begin{array}{r}-0.04+ \\
(0.08)\end{array}$ & $\begin{array}{c}-0.04+ \\
(0.07)\end{array}$ & $\begin{array}{l}0.09^{* * *} \\
(0.00)\end{array}$ & $\begin{array}{c}0.09^{* * *} \\
(0.00)\end{array}$ \\
\hline Supervision & $\begin{array}{l}0.09^{* * * *} \\
(0.00)\end{array}$ & $\begin{array}{l}0.09^{* * * *} \\
(0.00)\end{array}$ & $\begin{array}{l}0.15^{* * *} \\
(0.00)\end{array}$ & $\begin{array}{l}0.15^{* * * *} \\
(0.00)\end{array}$ & $\begin{array}{c}0.040^{* * *} \\
(0.00)\end{array}$ & $\begin{array}{l}0.04^{* * *} \\
(0.00)\end{array}$ \\
\hline Barriers & $\begin{array}{l}0.08^{* *} \\
(0.00)\end{array}$ & $\begin{array}{l}0.08^{* *} \\
(0.00)\end{array}$ & $\begin{array}{l}0.07^{* *} \\
(0.00)\end{array}$ & $\begin{array}{l}0.07^{* *} \\
(0.00)\end{array}$ & $\begin{array}{l}0.04^{*} \\
(0.02)\end{array}$ & $\begin{array}{l}0.04^{*} \\
(0.02)\end{array}$ \\
\hline Language & $\begin{array}{c}0.08 \\
(0.68)\end{array}$ & $\begin{array}{c}0.07 \\
(0.67)\end{array}$ & $\begin{array}{c}0.20 \\
(0.39)\end{array}$ & $\begin{array}{c}0.16 \\
(0.33)\end{array}$ & $\begin{array}{c}0.05 \\
(0.79)\end{array}$ & $\begin{array}{c}0.04 \\
(0.73)\end{array}$ \\
\hline Ethnic & $\begin{array}{l}-0.06 \\
(0.74)\end{array}$ & $\begin{array}{l}-0.04 \\
(0.80)\end{array}$ & $\begin{array}{l}-0.08 \\
(0.75)\end{array}$ & $\begin{array}{l}-0.02 \\
(0.92)\end{array}$ & $\begin{array}{l}-0.15 \\
(0.42)\end{array}$ & $\begin{array}{l}-0.17 \\
(0.16)\end{array}$ \\
\hline Malaria & $\begin{array}{l}-0.49^{*} \\
(0.02)\end{array}$ & $\begin{array}{l}-0.46^{*} \\
(0.01)\end{array}$ & $\begin{array}{l}-0.46+ \\
(0.08)\end{array}$ & $\begin{array}{l}-0.45^{*} \\
(0.02)\end{array}$ & $\begin{array}{l}-0.21 \\
(0.29)\end{array}$ & $\begin{array}{l}-0.29^{*} \\
(0.04)\end{array}$ \\
\hline Temperate & $\begin{array}{l}-0.62^{* *} \\
(0.01)\end{array}$ & $\begin{array}{l}-0.61^{* *} \\
(0.00)\end{array}$ & $\begin{array}{l}-0.68^{*} \\
(0.02)\end{array}$ & $\begin{array}{l}-0.67^{* *} \\
(0.00)\end{array}$ & $\begin{array}{l}-0.03 \\
(0.91)\end{array}$ & $\begin{array}{l}-0.05 \\
(0.76)\end{array}$ \\
\hline Religion & $\begin{array}{c}0.20 \\
(0.13)\end{array}$ & $\begin{array}{c}0.19 \\
(0.12)\end{array}$ & $\begin{array}{l}-0.02 \\
(0.91)\end{array}$ & $\begin{array}{l}-0.03 \\
(0.81)\end{array}$ & $\begin{array}{l}-0.12 \\
(0.37)\end{array}$ & $\begin{array}{l}-0.09 \\
(0.33)\end{array}$ \\
\hline ExternalDebt & $\begin{array}{l}-0.07^{*} \\
(0.02)\end{array}$ & $\begin{array}{l}-0.07^{*} \\
(0.02)\end{array}$ & $\begin{array}{c}0.05 \\
(0.11)\end{array}$ & $\begin{array}{c}0.04 \\
(0.14)\end{array}$ & $\begin{array}{c}-0.71^{* * *} \\
(0.00)\end{array}$ & $\begin{array}{c}-0.71^{* * *} \\
(0.00)\end{array}$ \\
\hline Savings & $\begin{array}{l}0.13^{* *} \\
(0.00)\end{array}$ & $\begin{array}{l}0.13^{* *} \\
(0.00)\end{array}$ & $\begin{array}{l}-0.01 \\
(0.75)\end{array}$ & $\begin{array}{l}-0.01 \\
(0.81)\end{array}$ & $\begin{array}{l}0.66^{* * *} \\
(0.00)\end{array}$ & $\begin{array}{l}0.67^{* * *} \\
(0.00)\end{array}$ \\
\hline Inflation & $\begin{array}{l}-0.00 \\
(0.86)\end{array}$ & $\begin{array}{l}-0.003 \\
(0.83)\end{array}$ & $\begin{array}{l}-0.02 \\
(0.24)\end{array}$ & $\begin{array}{l}-0.02 \\
(0.20)\end{array}$ & $\begin{array}{l}-0.00 \\
(0.96)\end{array}$ & $\begin{array}{l}-0.00 \\
(0.95)\end{array}$ \\
\hline ExchangeRate & $\begin{array}{l}-0.04 \\
(0.18)\end{array}$ & $\begin{array}{l}-0.04 \\
(0.16)\end{array}$ & $\begin{array}{c}-0.03 \\
(0.32)\end{array}$ & $\begin{array}{l}-0.03 \\
(0.28)\end{array}$ & $\begin{array}{c}-0.10^{* * * *} \\
(0.00)\end{array}$ & $\begin{array}{c}-0.10^{* * *} \\
(0.00)\end{array}$ \\
\hline$N$ & 732 & 732 & 720 & 720 & 804 & 804 \\
\hline
\end{tabular}

Standardized beta coefficients; $p$-values in parentheses

$+p<0.10,^{*} p<0.05,{ }^{* *} p<0.01,{ }^{* * *} p<0.001$

Exogenous $=$ ExternalDebt, Savings, Inflation, ExchangeRate, Language, Malaria, Ethnic,

Temperate, Religion. Endogenous = Competition, Property, Contract, Composite,

Privatization, Supervision, Barriers.

In contrast to the estimation results with Credit as the dependent variables, the estimations in Table 3 report that the policy indicators all have a significant coefficient. The models in column 1 to 4 suggest that privatization of the banking sector has a negative relation with the ratio of bank deposits to GDP and with the ratio of bank credit to the private sector to GDP. This finding is in line with that of Detragiache et al. (2008). Based on the results reported in column 5 and 6-with Investment as the dependent variable-we conclude that the privatization of banks is associated with high levels of investment as a proportion of GDP, albeit the magnitude of the effect is relatively small. 
Table 4 - Robustness Tests. AM Regression Results: Dependent Variable Credit

\begin{tabular}{|c|c|c|c|c|c|c|c|c|}
\hline & \multicolumn{4}{|c|}{ Models with lags } & \multicolumn{4}{|c|}{ Models with smoothed averages } \\
\hline & $(1)$ & $(2)$ & (3) & (4) & (5) & (6) & (7) & (8) \\
\hline \multirow[t]{2}{*}{ Competition } & $0.49^{* *}$ & & $0.40^{*}$ & & $0.54^{* *}$ & & $0.35+$ & \\
\hline & $(0.01)$ & & $(0.02)$ & & $\begin{array}{l}(0.00) \\
0.36 *\end{array}$ & & $(0.06)$ & \\
\hline \multirow{2}{*}{ Property } & $0.38^{*}$ & & $0.46^{* *}$ & & $0.36^{*}$ & & $0.57^{* * *}$ & \\
\hline & $(0.01)$ & & $(0.00)$ & & $(0.02)$ & & $(0.00)$ & \\
\hline \multirow[t]{2}{*}{ Contract } & $0.37^{*}$ & & $0.39^{* *}$ & & $0.50^{* * *}$ & & $0.45^{* *}$ & \\
\hline & $(0.01)$ & & $(0.01)$ & & $(0.00)$ & & $(0.00)$ & \\
\hline \multirow[t]{2}{*}{ Composite } & & $0.68^{* * *}$ & & $0.74^{* * *}$ & & $0.77^{* * *}$ & & $0.82^{* * *}$ \\
\hline & & $(0.00)$ & & $(0.00)$ & & $(0.00)$ & & $(0.00)$ \\
\hline \multirow[t]{2}{*}{ Privatization } & & & -0.01 & -0.01 & & & 0.02 & 0.02 \\
\hline & & & $(0.86)$ & $(0.85)$ & & & $(0.66)$ & $(0.64)$ \\
\hline \multirow[t]{2}{*}{ Supervision } & & & $0.06^{*}$ & $0.06^{* *}$ & & & 0.04 & 0.05 \\
\hline & & & $(0.01)$ & $(0.01)$ & & & $(0.21)$ & $(0.20)$ \\
\hline \multirow[t]{2}{*}{ Barriers } & & & $0.08^{* *}$ & $0.08^{*}$ & & & 0.07 & 0.07 \\
\hline & & & $(0.01)$ & $(0.01)$ & & & $(0.13)$ & $(0.15)$ \\
\hline \multirow[t]{2}{*}{ Language } & 0.06 & 0.06 & 0.02 & 0.01 & 0.02 & 0.03 & -0.02 & -0.04 \\
\hline & $(0.73)$ & $(0.65)$ & $(0.92)$ & $(0.97)$ & $(0.90)$ & $(0.84)$ & $(0.91)$ & $(0.81)$ \\
\hline \multirow[t]{2}{*}{ Ethnic } & -0.04 & -0.05 & -0.03 & -0.00 & 0.02 & -0.01 & -0.03 & 0.03 \\
\hline & $(0.83)$ & $(0.71)$ & $(0.88)$ & $(0.99)$ & $(0.89)$ & $(0.93)$ & $(0.88)$ & $(0.85)$ \\
\hline \multirow[t]{2}{*}{ Malaria } & $-0.33+$ & $-0.33^{*}$ & $-0.40+$ & $-0.39^{*}$ & $-0.30+$ & $-0.28+$ & $-0.34+$ & -0.32 \\
\hline & $(0.08)$ & $(0.03)$ & $(0.05)$ & $(0.03)$ & $(0.07)$ & $(0.09)$ & $(0.10)$ & $(0.11)$ \\
\hline \multirow[t]{2}{*}{ Temperate } & $-0.35+$ & $-0.34^{*}$ & $-0.60^{* *}$ & $-0.60^{* *}$ & $-0.35+$ & $-0.34+$ & $-0.59 * *$ & $-0.57^{*}$ \\
\hline & $(0.10)$ & $(0.03)$ & $(0.01)$ & $(0.00)$ & $(0.06)$ & $(0.06)$ & $(0.01)$ & $(0.01)$ \\
\hline \multirow[t]{2}{*}{ Religion } & 0.16 & 0.16 & 0.21 & $0.21+$ & 0.14 & 0.14 & 0.20 & 0.18 \\
\hline & $(0.24)$ & $(0.12)$ & $(0.11)$ & $(0.08)$ & $(0.22)$ & $(0.22)$ & $(0.12)$ & $(0.16)$ \\
\hline \multirow[t]{2}{*}{ ExternalDebt } & $-0.13^{* * *}$ & $-0.13^{* * *}$ & $-0.19^{* * *}$ & $-0.19^{* * *}$ & $-0.26^{* * *}$ & $-0.26^{* * *}$ & $-0.35^{* * * *}$ & $-0.36^{* * *}$ \\
\hline & $(0.00)$ & $(0.00)$ & $(0.00)$ & $(0.00)$ & $(0.00)$ & $(0.00)$ & $(0.00)$ & $(0.00)$ \\
\hline \multirow[t]{2}{*}{ Savings } & $0.16^{* * *}$ & $0.16^{* * *}$ & $0.29^{* * *}$ & $0.29^{* * *}$ & $0.29^{* * *}$ & $0.29^{* * *}$ & $0.49^{* * *}$ & $0.47^{* * *}$ \\
\hline & $(0.00)$ & $(0.00)$ & $(0.00)$ & $(0.00)$ & $(0.00)$ & $(0.00)$ & $(0.00)$ & $(0.00)$ \\
\hline \multirow[t]{2}{*}{ Inflation } & $-0.03^{*}$ & $-0.03^{* *}$ & -0.03 & -0.03 & $-0.04^{*}$ & $-0.04^{*}$ & -0.03 & -0.04 \\
\hline & $(0.01)$ & $(0.01)$ & $(0.11)$ & $(0.10)$ & $(0.02)$ & $(0.02)$ & $(0.20)$ & $(0.16)$ \\
\hline \multirow[t]{2}{*}{ ExchangeRate } & -0.01 & -0.01 & -0.03 & -0.04 & -0.01 & -0.02 & -0.04 & -0.04 \\
\hline & $(0.69)$ & $(0.63)$ & $(0.33)$ & $(0.30)$ & $(0.72)$ & $(0.65)$ & $(0.37)$ & $(0.35)$ \\
\hline$N$ & 891 & 891 & 671 & 671 & 648 & 648 & 488 & 488 \\
\hline
\end{tabular}

Standardized beta coefficients; $p$-values in parentheses

$+p<0.10,^{*} p<0.05,{ }^{* *} p<0.01,{ }^{* * *} p<0.001$

Exogenous = ExternalDebt, Savings, Inflation, ExchangeRate, Language, Malaria, Ethnic,

Temperate, Religion. Endogenous = Competition, Property, Contract, Composite. 
Overall, both the formalization of institutional characteristics and financial policy are important for countries' financial market. Nevertheless, the differences across the models support the thesis that the development of formal institutions is a stage by stage process.

\subsection{Robustness}

The dynamics are further explored by lagging the TV macroeconomic and policy variables by one year. The importance of substituting a current value with a one year lag may be relevant for the estimation of some countries. The regulatory processes to obtain credit may be relatively slower in countries that have relatively low levels of credit. The estimation results with the lagged variables are reported in Table 4 column 1, 2, 3, and 4 . The estimations for the institutional indicators are positive and significant; several coefficients of institutional indicators are lower than the coefficients of institutional indicators presented in Table 1 and Table 2. In addition, we smooth the TV data into five year average levels and growth rates. Current values are substituted for the average of the observations in the current year and for those in the previous four years. The results are presented in Table 4 column 5,6,7, and 8 . The institutional variables remain positive and significant. However, the policy indicators are not significant. This supports the thesis that financial policy only has an effect on short term macroeconomic changes.

\section{Conclusion}

The results of this study only partially confirm those of Acemoglu and Johnson (2005). Following these authors' conclusive argument, property rights institutions are related to countries' level of credit to the private sector. However, the authors find that contracting institutions do not matter for credit deepening. Our findings are in line with the conclusions drawn by La Porta et al. (2000) who argue that creditor rights, which protect investors from expropriation, encourages financial development. We find empirical evidence that suggests a strong positive relationship between credit deepening and the development of formal property rights, contracting, and competition institutions. Our results also suggest that only property rights and contracting institutions are related to banks' lending capacity, and that only competition institutions are positively related to investment. Based on a broader indicator of institutional development we conclude that the development of formal institutions is positively related to financial deepening and to the ratio of investment to GDP.

The financial sector is an important intermediating factor in the institutions - growth relationship. Before the crisis, formal institutional rules were generally described as beneficial because of their association with high vol- 
umes of credit. Since the crisis, more focus is on understanding the extent to which credit deepening is beneficial for economic growth. We emphasize that a lack of credit to the private sector is expected to form an obstacle to growth and development.

This study documents why institutional characteristics are difficult to measure. On the one hand, composite institutions / governance indicators as well as broad institutional surveys can not be used to assess a country's performance on specific institutional aspects. On the other hand, specific institutional aspects are closely related amongst each other and are closely related to composite indicators. Therefore, we estimate the relation of closely related institutional characteristics by constructing orthogonal institutional indicators. Policymakers need to be careful when assessing a country's institutional development. Because of the interrelatedness of the institutional characteristics, institutions may be best documented on the basis of a more general institutional dimension.

This study would benefit from further analysis on the relation between institutional characteristics, credit markets, investment, and growth. Additional questions that arise include: Under what institutional conditions does credit deepening have a positive effect on growth? What is the effect of institutional formalization on informal lending? 


\section{References}

Abiad, A., Detragiache, E., Tressel, T., 2010. A New Database of Financial Reforms. IMF Staff Papers 57, 281-302. doi:10.1057/imfsp.2009.23

Acemoglu, D., Johnson, S., 2005. Unbundling institutions. Journal of Political Economy 113, 949-995. doi:10.1086/432166

Acemoglu, D., Johnson, S., Robinson, J.A., 2001. The Colonial Origins of Comparative Development: An Empirical Investigation. American Economic Review 91. 1369-1401. doi:10.1257/aer.91.5.1369

Albouy, Y.D., 2012. The Colonial Origins of Comparative Development: An Empirical Investigation: Comment. American Economic Review 102, 30593076. doi:10.1257/aer.102.6.3059

Alesina, A., Devleeschauwer, A., Easterly, W., Kurlat, S., Wacziarg, R., 2003. Fractionalization. Journal of Economic Growth 8, 155-94. doi:10.1023/A:1024471506938

Amemiya, T., MaCurdy, T.E., 1986. Instrumental-Variable Estimation of an Error-Components Model. Econometrica 54, 869-80. doi:10.2307/1912840

Andrianova, S., Demetriades, P.O., Shortland, A.K., 2008. Government Ownership of Banks, Institutions, and Financial Development. Journal of Development Economics 85, 218-252. doi:10.1016/j.jdeveco.2006.08.002

Arcand, J.L., Berkes, E., Panizza, U., 2013. Finance and Economic Development in a Model with Credit Rationing? Graduate Institute of International and Development Studies Working Paper, 02/2013.

Arcand, J.L., Berkes, E., Panizza, U., 2012. Too much Finance? IMF Working Paper, 12.

Bae, K., Goyal, V.K., 2009. Creditor Rights, Enforcement, and Bank Loans. Journal of Finance 64, 823-860. doi:10.1111/j.1540-6261.2009.01450.x

Beck, N. Katz, J.N., 1995. What To Do (and Not To Do) with Time-Series Cross-Section Data. The American Political Science Review 89, 634-647. doi:10.2307/2082979

Beck, T., Demirguc-Kunt, A., Levine, R., 2009. Financial Institutions and Markets Across Countries and Over Time-Data and Analysis. Policy Research Working Paper Series 4943, The World Bank, May 2009.

Breusch, T., Ward, M.B., Hoa, T.N., Kompas, T., 2011. FEVD: Just IV or Just Mistaken? Political Analysis 19, 123-134. doi:10.1093/pan/mpq026 
Chatelain, J., Ralf, K., 2010. Inference on Time-Invariant Variables Using Panel Data: A Pre-Test Estimator with an Application to the Returns to Schooling. Pse working papers, HAL.

De Crombrugghe, D., 2010. Unity in Diversity: Studies on Micro and Macro Panel Data Sets. PhD thesis, Maastricht Univeristy. Chapter 6.

Detragiache, E., Tressel, T., Gupta, P., 2008. Foreign Banks in Poor Countries: Theory and Evidence. Journal of Financial Economics LXIII, 2160-2123.

Djankov, S., McLiesh, C., Shleifer, A., 2007. Private Credit in 129 Countries. Journal of Financial Economics 84, 299-329. doi:10.1016/j.jfineco.2006.03.004

Engerman, S.L., Sokoloffm K.L., 1997. Factor Endowments, Institutions and Differential Paths of Growth Among New World Economies. In Calif. Stanford (Ed.), How America Fell Behind, Stanford Univeristy press. pp. 260304.

Gallup, J.L., Mellinger, A.D., Sachs, J.D., 2001. Geography Datasets, Center for International Development.

Gilchrist, S., Sim, J.M., Zakrajšek, E., 2013. Missallocation and Financial Market Frictions: Some Direct Evidence from the Dispersion in Borrowing Costs. Review of Economic Dynamics 16, 159-176.

Glaeser, E.L., La Porta, R., Lopez-de Silanes, F., Shleifer, A., 2004. Do Institutions Cause Growth? Journal of Economic Growth 9, 271-303. doi:10.1023/B:JOEG.0000038933.16398.ed

Greene, W., 2011. Fixed Effects Vector Decomposition: A Magical Solution to the Problem of Time Invariant Variables in Fixed Effects Models? Political Analysis 19, 135-406. doi:10.1093/pan/mpq034

Greenwood, J., Sanchez, J.M., and Wang, C., 2013. Quantifying the Impact of Financial Development on Economic Development. Review of Economic Analysis 16, 194-215.

Greenwood, J., Sanchez, J.M., and Wang, C., 2010. Financing Development: the Role of Information Costs. American Economic Review 100, 1975-1891. doi:10.1257/aer.100.4.1875

Greif, A., Tabellini, G., 2010. Cultural and Institutional Bifurcation: China and Europe Compared. American Economic Review 100, 135-40. doi:10.1257/aer.100.2.135

Hasan, I., Wachtel, P., Zhou, M., 2009. Institutional Development, Financial Deepening and Economic Growth: Evidence from China. Journal of Banking \& Finance 33, 157-170. doi:10.1016/j.jbankfin.2007.11.016 
Hausman, J.A., Taylor, W.E., 1981. Panel Data and Unobservable Individual Effects. Econometrica 49, 1377-1398. doi:10.2307/1911406

Heston, A., Summers, R., Aten, B., 2009. Penn World Table 6.3 .

IPD, 2009. Institutional Profiles Database.

Jeong, H., Townsend, R.M., 2007. Sources of TFP Growth: Occupational Choice and Financial Deepening. Economic Theory 32, 179-221.

Kindleberger, C.P., Aliber, R., 2005. Manias, Panics, and Crashes: A History of Financial Crises. Wiley, 5th edition. doi:10.1057/9780230628045

La Porta, R., Lopez-de Silanes, F., Shleifer, A., Vishny, R., 2000. Investor Protection: Origins, Consequences, Reform. The World Bank. Financial Sector Discussion Paper No.1.

La Porta, R., Lopez-de Silanes, F., Shleifer, A., 2002. Government Ownership of Banks. Journal of Finance 57, 265-301. doi:10.1111/1540-6261.00422

Levine, R., 2005. Law, Endowments and Property Rights. Journal of Economic Perspectives 19, 61-88. doi:10.1257/089533005774357842

Marshall, M.G., Jaggers, K., 2009. Polity IV Project. Center for Global Policy and School of Public Policy and George Mason University and Center for Systemic Peace. Dataset Users' Manual.

Minsky., H.P., 1986. Stabilizing an Unstable Economy. Yale University Press.

Plumper, T., Troeger, V.E., 2011. Fixed-Effects Vector Decomposition: Properties, Reliability, and Instruments. Political Analysis 19, 147-164. doi:10.1093/pan/mpr008

Quintyn, M., Verdier, G., 2010. "Mother, Can I Trust the Government?" Sustained Financial Deepening - A Political Institutions View. IMF Working Paper 210.

Reinhart, C.M., Rogoff, K., 2009. This Time Is Different: Eight Centuries of Financial Folly. Princeton University Press.

Spolaore, E., Wacziarg, R., 2013. How Deep are the Roots of Economic Decelopment? Journal of Economic Literature 52, 325-369. doi:10.1257/jel.51.2.325

Tchakoute-Tchuigoa, H., 2012. Active Risk Management and Loan Contract Terms: Evidence from Rated Microfinance Institutions. The Quarterly Review of Economics and Finance 52, 427-437. 
Tressel, T., Detragiache, E., 2008. Do Financial Sector Reforms Lead to Financial Development? Evidence from a New Dataset. IMF Working Paper 265.

UNCTAD, 2007. Model Law on Competition. Technical report, United Nations.

World Bank, 2011. World Development Indicators.

Yeyati, E.L., Micco, M., Panizza, U., Detragiache, D., Repetto, A. 2007. A Reappraisal of State-Owned Banks. Economia 7, 209-259. 


\section{Appendix}

\section{A Countries}

Table 5 - Country List

\begin{tabular}{|l|l||l|l||l|l|}
\hline Code & Country & Code & Country & Code & Country \\
\hline ARG & Argentina & GHA & Ghana & PAK & Pakistan \\
AUS & Australia & GRC & Greece & PAN & Panama \\
BEN & Benin & GTM & Guatemala & PER & Peru \\
BFA & Burkina Faso & HND & Honduras & PHL & Philippines \\
BGD & Bangladesh & HUN & Hungary & POL & Poland \\
BOL & Bolivia & IND & India & PRT & Portugal \\
BWA & Botswana & IRL & Ireland & QAT & Qatar \\
CAF & Central African & ISR & Israel & ROM & Romania \\
& Republic & & & & \\
CAN & Canada & ITA & Italy & RUS & Russia \\
CHE & Switzerland & JOR & Jordan & SAU & Saudi Arabia \\
CHN & China & KEN & Kenya & SDN & Sudan \\
CIV & Cote d'Ivoire & KOR & Korea, Rep. & SEN & Senegal \\
CMR & Cameroon & KWT & Kuwait & SVK & Slovak Republic \\
COL & Colombia & LBY & Libya & SVN & Slovenia \\
CYP & Cyprus & LKA & Sri Lanka & SWE & Sweden \\
CZE & Czech Republic & LTU & Lithuania & SYR & Syria \\
DEU & Germany & LVA & Latvia & TCD & Chad \\
DNK & Denmark & MAR & Morocco & TGO & Togo \\
DOM & Dominican $\quad$ Re- & MDG & Madagascar & THA & Thailand \\
& public & & & \\
DZA & Algeria & MEX & Mexico & TUN & Tunisia \\
ECU & Ecuador & MLI & Mali & TUR & Turkey \\
EGY & Egypt & MNG & Mongolia & TZA & Tanzania \\
ESP & Spain & MOZ & Mozambique & UGA & Uganda \\
EST & Estonia & MYS & Malaysia & Uruguay \\
FIN & Finland & NER & Niger & VSA & United States \\
GAB & Gabon & NPL & Nepal & Venezuela \\
GBR & United Kingdom & NZL & New Zealand & ZAF & South Africa \\
\hline
\end{tabular}




\section{B Data Sources}

Credit: Domestic credit to private sector (World Bank, 2011) \% of GDP.

BankCredit: Domestic credit provided by banking sector (World Bank, 2011) $\%$ of GDP.

BankDeposit: Deposits of deposit monetary institutions (Beck et al., 2009) $\%$ of GDP.

Investment: Investment, Current Price National Accounts at PPPs (Heston et al., 2009) \% of GDP.

Property, Contract, Competition, Composite: Institutional indicators (IPD, 2009) Indicators are normalized on a scale of $0=$ low formalization of rules to 1 = high formalization of rules. Original data ranges from 0-4 and 1-4.

Supervision: Prudential regulations and supervision of the banking sector ((Abiad et al., 2010$)$ From $0=$ unregulated, to $3=$ regulated.

Privatization: State ownership in the banking sector (Abiad et al., 2010) From $0=$ repressed, to $3=$ liberalized.

Barriers: Entry barriers in the banking sector (Abiad et al., 2010) From $0=$ repressed to $3=$ liberalized.

Inflation: Rate of change in the consumer price index (World Bank, 2011) $\%$ change.

Savings: Gross domestic savings (World Bank, 2011) \% of GDP.

ExternalDebt: External balance on goods and services (World Bank, 2011) $\%$ of GDP.

ExchangeRate: Exchange rate (Heston et al., 2009) US $=1$.

Malaria: Population at risk of malaria transmission in 1994 World Health Organization 1997 / (Glaeser et al. 2004) Probability of $0=$ no malaria risk to 1 = high malaria risk.

Temperate: Population in Koeppen-Geiger Climatic zone in 1995 (Gallup et al. 2001) \% of population.

Religion: Religious fractionalization (Alesina et al., 2003) Probability of $0=$ homogenous to 1 = fractionalized society.

Ethnic: Ethnic fractionalization (Alesina et al., 2003) Probability of $0=$ homogenous to 1 = fractionalized society.

Language: Linguistic fractionalization (Alesina et al., 2003) Probability of 0 $=$ homogenous to $1=$ fractionalized society. 